Article

\title{
Spatial-Temporal Characteristics and Climatic Responses of Water Level Fluctuations of Global Major Lakes from 2002 to 2010
}

\author{
Chao Tan, Mingguo Ma * and Honghai Kuang \\ Chongqing Key Laboratory of Karst Environment, School of Geographical Sciences, Southwest University, \\ Chongqing 400715, China; tc2533844258@email.swu.edu.cn (C.T.); hhkuang@swu.edu.cn (H.K.) \\ * Correspondence: mmg@swu.edu.cn; Tel.: +86-23-6825-3912
}

Academic Editors: Chunqiao Song, Qiusheng Wu, Deepak R. Mishra and Prasad S. Thenkabail Received: 17 December 2016; Accepted: 9 February 2017; Published: 13 February 2017

\begin{abstract}
As one of the most important geographical units affected by global climate change, lakes are sensitive to climatic changes and are considered "indicators" of climate and the environment. In this study, changes in the spatial-temporal characteristics of the water levels of 204 global major lakes are systematically analyzed using satellite altimetry data (Hydroweb product) from 2002 to 2010. Additionally, the responses of the major global lake levels to climatic fluctuations are analyzed using Global Land Surface Assimilation System (GLDAS) data (temperature and precipitation). The results show that the change rates of most global lakes exceed 0 , which means that the lake levels of these lakes are rising. The change rates of the lake levels are between $-0.3 \sim 0.3 \mathrm{~m} / \mathrm{a}$, which indicates that the rate of change in the water-level of most lakes is not obvious. A few lakes have a particularly sharp change rate, between $-5.84 \sim-2 \mathrm{~m} / \mathrm{a}$ or $0.7 \sim 1.87 \mathrm{~m} / \mathrm{a}$. Lakes with increasing levels are mainly located in the mountain and plateau regions, and the change rates in the coastal highlands are more evident. The global temperatures rise by a change rate of $0.0058^{\circ} \mathrm{C} / \mathrm{a}$, while the global precipitation decreases by a change rate of $-0.6697 \mathrm{~mm} / \mathrm{a}$. However, there are significant regional differences in both temperature and precipitation. In addition, the impact of precipitation on the water level of lakes is significant and straightforward, while the impact of temperature is more complex. A study of lake levels on a global scale would be quite useful for a better understanding of the impact which climate change has on surface water resources.
\end{abstract}

Keywords: lake change; temperature; precipitation; remote sensing

\section{Introduction}

Global environmental change, which is at the core of global climate change, has received considerable attention from governments since the 1980s [1]. The morphology and ecology of lakes have significantly changed over the past few decades, as they are affected by climate change and human activities [2]. The world's lake area accounts for approximately $1.8 \%$ of the Earth's total land surface area, and there are up to 8 million lakes with areas greater than 1 hectare [3]. As one type of wetland, lakes play an active role in the natural water circulation, providing functions such as water storage, groundwater replenishment, local temperature, ecological structure regulation, and biological diversity maintenance. However, the desiccation of lakes, such as the Aral Sea, has severe negative impacts, including the end of commercial fishing industries and the devastation of the floral and faunal biodiversity of the native ecosystems [4]. Therefore, it is necessary to increase the investigation of global lakes and study the characteristics of lake areas and water levels in both time and space [5-7].

The changes of a lake are mainly reflected by the changes of the water level and area. The measurement of a lake level or lake area can reflect the change of corresponding lake features, 
because of the high correlation between the lake water level and the lake area [8]. Changes in the lake level can be recorded more clearly and be observed more easily [9]. Lake water level data are some of the most important and basic data in lake hydrological analyses, and are mainly measured by field observation stations in a traditional manner. Due to economic and political factors, many regions cannot provide observational data because of a lack of hydrological observatories. In addition, the global hydrological observation network sites have been reduced over the past few decades. After many years of development, satellite and laser radars can currently provide useful data for the study of lakes, rivers, and oceans [10-15]. Duan and Bastiaanssen used four operational satellite altimetry databases to estimate water volume variations in lakes and reservoirs, and compared these with the measured water level; the accuracy of ICESat-derived water levels is found to be within $11 \mathrm{~cm}$ for Lake Tana, Ethiopia [10]. Furthermore, Muala et al. found that there is a $20 \mathrm{~cm}$ level of accuracy for Roseires Reservoir, compared to in-situ water levels [11]. Medina et al. used satellite altimetry and imagery data to estimate the reservoir discharges from Lake Nasser and Roseires Reservoir in the Nile Basin. For Roseires Reservoir, the water levels from Hydroweb were in good agreement with in-situ water levels (RMSE $=0.92 \mathrm{~m} ; \mathrm{R}^{2}=0.96$ ). For Lake Nasser, the altimetry water levels from Hydroweb were also in good agreement with in-situ levels (RMSE $\left.=0.72 \mathrm{~m} ; \mathrm{R}^{2}=0.81\right)$ [12]. In recent years, many scholars have applied high-resolution ICESat altimetry data to study the water level changes [16-20], and the results are well verified.

After more than ten years of development, the Global Land Data Assimilation System (GLDAS) has been widely used to study global changes, the water cycle, and comparative analyses, with other remote sensing products [21-25]. Li et al. analyzed the applicability of GLDAS data in the source regions of the Yellow River, using the observed temperature and precipitation data from 1979 to 2010. The results of this study show that the GLDAS temperature and precipitation data can sufficiently indicate the spatial distribution characteristics, and the laws of temperature and precipitation of the source region [23]. Wang et al. analyzed the spatial features of the precipitation trend in China, by comparing GLDAS precipitation data to the monthly precipitation data of China from 1979 to 2012, concluding that the data quality of GLDAS-2 is evidently better than that of GLDAS-1 [22]. In this study, we utilize the entire area of the Earth as the study area. However, the existing meteorological sites are mostly located in economically developed and densely populated areas. The distributions of meteorological stations in some regions (such as the Qinghai-Tibet Plateau) are sparse, and global climate change research requires high-resolution grid data. Therefore GLDAS data provide valuable information to fill these observational gaps [26].

At present, for the lake level research, most scholars focus on the study of individual lakes, and some scientists pursue research on lakes of the hot spot regions, such as the Qinghai-Tibet Plateau and central Asia [27,28]. To our knowledge, few scholars study lake levels at the global scale. Although a few scholars study global water resources [29], there is no individual analysis for the global lakes. Most researchers do not use quantitative analysis, but instead use qualitative explanations for understanding the influencing factors of lake levels. Therefore, we systematically analyze the temporal and spatial characteristics of the major lakes throughout the world and the response to climatic changes, using the satellite altimetry data (Hydroweb product) and climate data (GLDAS) from 2002 to 2010. The first objective of this study is to analyze the spatiotemporal variation of the water level of major lakes at the global scale. The second objective is to quantitatively determine the influence of climatic factors, such as temperature and precipitation, on the water level changes of the major lakes throughout the world.

\section{Materials and Methods}

\subsection{Lake Level Data}

The development of satellite altimetry makes it possible to monitor the changes of lake levels accurately and continuously. In this study, the water level data of 204 lakes are obtained from the 
Hydroweb $[30,31]$ that is developed by LEGOS/GOHS (Laboratoire d'Etudes en Oceanographie et Geode'sie Spatiale, Equipe Geodesie, Oceanographie, et Hydrologie Spatiales) in France. The altimetry data are derived from Topex/Poseidon, ERS-1 and 2, Envisat, Jason-1, and GFO satellites. The time series of the lake level are of one-month temporal resolution, and the water level for some lakes constitutes that from 1992 to present [32]. The reference of the water level is the GRACE Gravity Model 02 (GGM02) geoid. Cretaux et al. described the detailed procedure for water level processing in Hydroweb, which mainly provides the lake level, water storage, and lake area. Many scholars have found that the Hydroweb product provides accurate water level variation, when compared with gauge data. Especially for big lakes, the accuracy is less than $5 \mathrm{~cm} \mathrm{rms} \mathrm{[33,34].} \mathrm{However,} \mathrm{the} \mathrm{technique} \mathrm{is} \mathrm{less}$ accurate for smaller lakes, and the oscillation of the derived level variations are higher than the total error budget $[35,36]$. In this study, the time series of 204 lakes include nine complete years from 2002 to 2010, because some lakes don't have water level data in some years. The change rate of the water level for each lake is calculated in a spreadsheet (Microsoft Excel) and all change rates are categorized into six levels, using ArcGIS 10.2 (ESRI, Redland, CA, USA) (Figure 1).

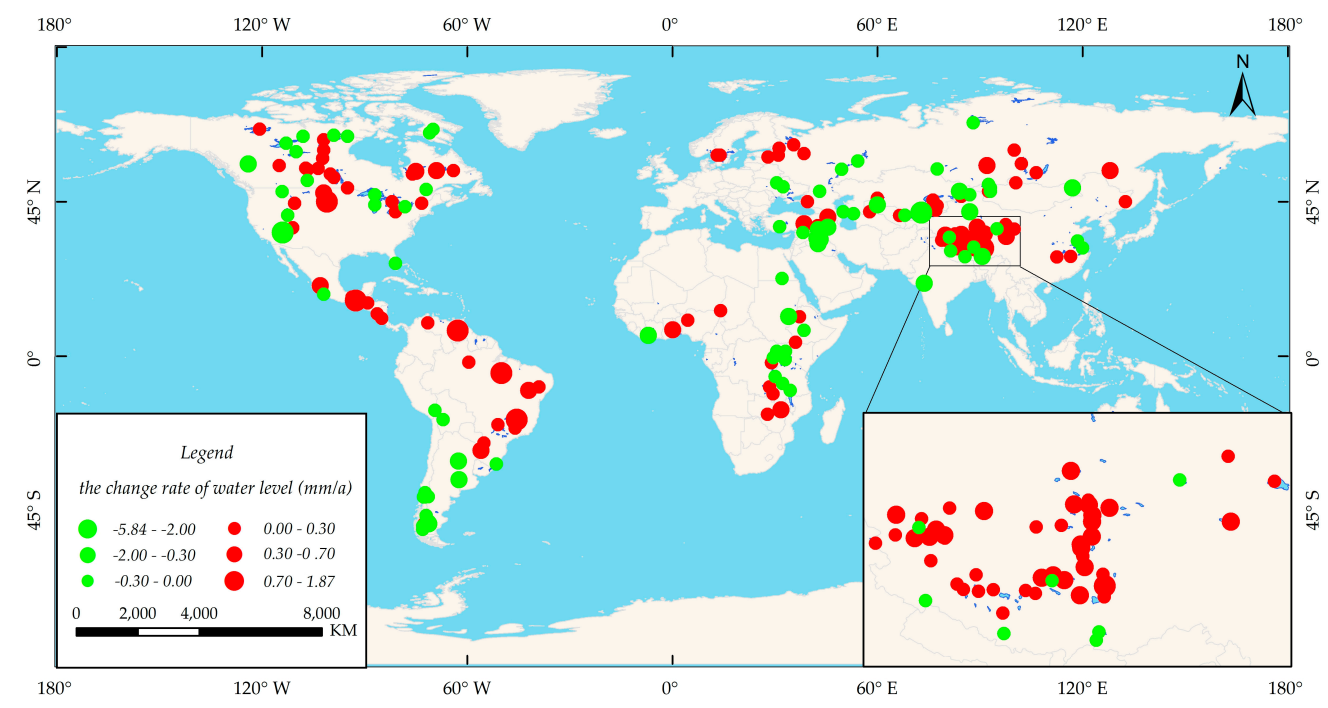

Figure 1. Classification of the change rates of lake levels.

\subsection{Watershed Data}

Watershed data with a $450 \mathrm{~m}$ spatial resolution are downloaded from the USGS (U.S. Geological Survey) HydroSHEDS [37]. HydroSHEDS is based on high-resolution elevation data, obtained during a Space Shuttle flight as part of NASA's Shuttle Radar Topography Mission (SRTM). It is a scientific project that provides hydrological information, including basin boundaries, river networks, water flow direction, and water accumulation from $60^{\circ} \mathrm{N}$ to $60^{\circ} \mathrm{S}$, in a consistent and comprehensive format for regional and global applications. In this paper, 103 watersheds are used to calculate the mean value of the change rates of 138 natural lake levels and other data in the watershed, using the Zonal Statistics in ArcGIS. However, some lakes with a high (more than $60^{\circ}$ ) latitude can't be included in the watershed, because watershed data are only in the range of $60^{\circ} \mathrm{N}-60^{\circ} \mathrm{S}$.

\subsection{Meteorological Data}

Temperature and precipitation data are acquired from the Global Land Assimilation System (GLDAS) [38]. GLDAS is a global high-resolution land-based simulation system that generates globally-optimized surface state variables and flux data by incorporating ground-based observations and satellite observations, providing 28 variables in the surface process, including temperature, precipitation, radiation, soil moisture, soil temperature, and wind speed. In this paper, precipitation 
data with a $3 \mathrm{~h}$ temporal resolution and 0.25-degree spatial resolution, and temperature data with a one-month temporal resolution and 0.25-degree spatial resolution, from the GLDAS-2Noah model, are downloaded for the years between 2002 and 2010. Temperature and precipitation are extracted from the GLDAS data using MATLAB (Matrix Laboratory, Math Works) software. Meanwhile, the precipitation data are synthesized every three hours, in relation to the monthly totals.

The images of temperature and precipitation are synthesized every month to the year, using the program codes and the trend line of temperature and precipitation which have been calculated for between 2002 and 2010.The change rates of the linear time trends are calculated using an ordinary least squares (OLS) estimation (see Equation (1)). The correlation between the change rates of the lake levels, and the change rates of the temperature and precipitation, is analyzed in SPSS 19.0 (Statistical Product and Service Solutions, IBM, America), after accounting for the mean change rates of the temperature and precipitation in the watershed.

$$
\text { Slope }=\frac{n \times \sum_{i=1}^{n} i \times \text { Aveyear }_{i}-\left(\sum_{i=1}^{n} i\right)\left(\sum_{i=1}^{n} \text { Aveyear }_{i}\right)}{n \times \sum_{i=1}^{n} i^{2}-\left(\sum_{i=1}^{n} i\right)^{2}}
$$

$n$ represents the number of years. $i=1$ for 2002, $i=2$ for 2003 etc. Aveyear $i$ is the mean value of $i$ year in the region (temperature, precipitation). "Slope" is the change rate of a linear regression equation, indicating that the factor is an increasing trend in the $n$-year if the slope is more than 0 , otherwise it is decreasing. The greater the ISlopel is, the more obvious the trend becomes.

We calculate the accumulated precipitation and temperature in the drainage basin, in order to effectively account for the change rate relationships of the lake level, precipitation, and temperature. As an example, we can produce the data of the accumulated precipitation by adding all of the differences between the values, after using the annual rainfall to minus the precipitation of the base year (2002).

\section{Results}

\subsection{Temporal and Spatial Characteristics of Major Global Lakes}

\subsubsection{Time Characteristics of the Lake Water Level Changes}

Using the lake water level data, we analyze the changing trend of the water level of 204 lakes throughout the world, from 2002 to 2010 (Appendix A). Lakes are ranked according to the mass distribution map of the change rates of the lake levels (Figure 1). The results are as follows.

The global lake level shows a rising trend. A total of 124 lakes, accounting for $2 / 3$ of the total number, have increasing water levels. There are 80 lakes with decreasing water levels, which accounts for approximately $1 / 3$ of the total number.

Of the 80 lakes for which the water level is dropping, more than 60 of these lakes present little change, with change rates between $-0.03-0 \mathrm{~m} / \mathrm{a}$. Only a few lakes show obvious changes, such as the Toktogul Reservoir, and the Lake Mead, Yamzho-Yumco. The Yamzho-Yumco stands on the Tibetan Plateau and has shrunk rapidly in recent decades, including a significant decline in the water level $[31,39,40]$. Of the 124 lakes with an increasing water level, approximately 85 of those lakes show a small change in the trend of the water level, and the change rates are primarily around $0-0.3 \mathrm{~m} / \mathrm{a}$. Approximately six lakes have change rates ranging from 0.7 to $1.87 \mathrm{~m} / \mathrm{a}$, for which the water levels have clearly increased.

The water level fluctuation of natural lakes is smaller than that of artificial lakes (reservoirs). Of the 56 artificial lakes, 39 of those lakes show an increasing water level trend, and only 17 reservoirs have declining water levels. Of the 148 natural lakes, 138 are within the studied watershed, and the water levels of 93 of these lakes are rising, while 45 lakes have declining water levels. A total of 51 natural lakes are located on the Qinghai-Tibet Plateau, an environmentally unique area. The Qinghai-Tibet Plateau is known as the "roof of the world" and its average elevation surpasses 
$4000 \mathrm{~m}$. The hydrological environment is less disturbed by human activities; thus, the change in the lake water level reflects the change in the global climate. The area of individual lakes in the Qinghai-Tibet Plateau is relatively small compared to other lakes in the world, but most lakes are inland lakes, and are more sensitive to climate change and variation. The analysis shows that the water level of the 44 lakes is constantly increasing, accounting for $86 \%$ of the total number of lakes on the Qinghai-Tibet Plateau. Only a few lakes (Yamzho-yumco, Pelkhu-co, Puma-yumco, and Mapam-yamco) have water levels that are decreasing.

\subsubsection{Spatial Characteristics of Lake Water Level Change}

As a geographical unit directly affected by climate change, a lake plays a major role in studies of global climate change [3]. The responses of a specific region to global climate change can lead to significant regional differences in lake water levels (Figure 1). The global lakes are divided into the following four regions for analysis.

\section{(1) Asia and European continent}

The lakes in Asia and Europe are widely distributed. A total of 110 in Asia and Europe are studied in this paper, 74 of which have rising water levels, accounting for $67 \%$ of the total number of lakes in this area. Most of the lakes are located on the Qinghai-Tibet Plateau, north of the Himalayas, and south of the Kunlun Mountains. The water levels of the lakes on the Qinghai-Tibet Plateau are found to rise significantly during the study period. The distribution of the other lakes is relatively broad, with lakes located on the Scandinavian Peninsula in northern Europe, the Eastern European Plain, the Asia Minor peninsula, the Caucasus, East Central Asia, north of the Tianshan Mountains in the Central Asian Mountains, and the Siberian Plateau. A total of 36 lakes with declining water levels are scattered and dispersed throughout the region, but are mainly located in the Valley of the Yarlung Zangbo River, which lies on the south side of the Himalayas, Altai Mountains, and Mesopotamia. The water levels of the lakes in the Kazakh Hills, southern Central Asia, and Central Europe, are slowly declining. Of the 110 lakes, we found that there are 23 reservoirs with an obvious regional difference in the changes of the water level. Seven reservoirs with rising water levels are mainly located in a region of higher latitude. However, 18 reservoirs with decreasing levels are distributed in a region of middle latitude, especially the arid zone and semi-arid region.

\section{(2) South America}

In this study, there are 27 lakes included from South America. A total of 12 lakes with increasing water levels, are mainly distributed in eastern South America, the Brazilian plateau, and the Amazon plain on the Atlantic coast. The increasing water level of the lakes on the Brazilian plateau is more evident than in the other areas. The water level of 15 lakes is decreasing, mainly in western South America. The water levels of the lakes that are located the eastern side of the Andes, in particular on the southern tip of the Andes, are evidently declining. A total 13 reservoirs are located in South America. The water levels of 12 of these reservoirs, which are mainly distributed in the east of South America, are increasing.

\section{(3) North America}

There are 46 lakes in North America. The number of lakes with water levels rising is 28 , accounting for more than $2 / 3$ of the total number of lakes in the area. The lakes with declining water levels are mainly located in the Central Plains of North America, the Labrador Peninsula in the east and the Mexican plateau. One-third of the lakes with decreasing water levels are located in the east of the Rocky Mountains and in northern North America, and lake levels are decreasing at a faster rate near the Arctic Ocean. Of the 46 lakes in North America, 10 reservoirs with rising water levels are mainly located the middle-eastern part of North America. However, 12 reservoirs with decreasing levels are mainly distributed in the west and north of North America. 


\section{(4) Africa}

There are 21 lakes in Africa. There is no significant difference in the number of lakes with increasing water levels and the number of lakes with descending water levels. A total of 11 lakes have declining water levels and are mainly distributed in the East African Great Rift Valley and East African Plateau. The 10 lakes with increasing water levels are relatively scattered throughout the Sudan steppe, the Ethiopian Plateau, and the South African plateau. Only the Volta reservoir, situated downstream of Volta River, and Lake Cahora Bassa, which stands on the South African Plateau, have higher water-level rise rates, while others only present small increases in the lake water level. Of four reservoirs included in this study, three have water levels which are rising, and are located in the south of the Sultan grassland, as well as at the middle reaches of the rivers.

\subsection{Global Climate Fluctuations}

Climate change, one of the most important current global issues, is related to the development of sustainable economic and social practices. In recent years, global floods, droughts, and other extreme climatic events, caused by global climate change, have been increasing [41,42]. In this paper, the GLDAS-2Noah model is used to analyze global climate change from 2002 to 2010 , at 0.25 degree spatial resolution, and a monthly temporal resolution of precipitation and temperature data. Temperature and precipitation trends are graded using the histogram distribution of the temperature and precipitation change rates in ArcGIS (Figure 2).
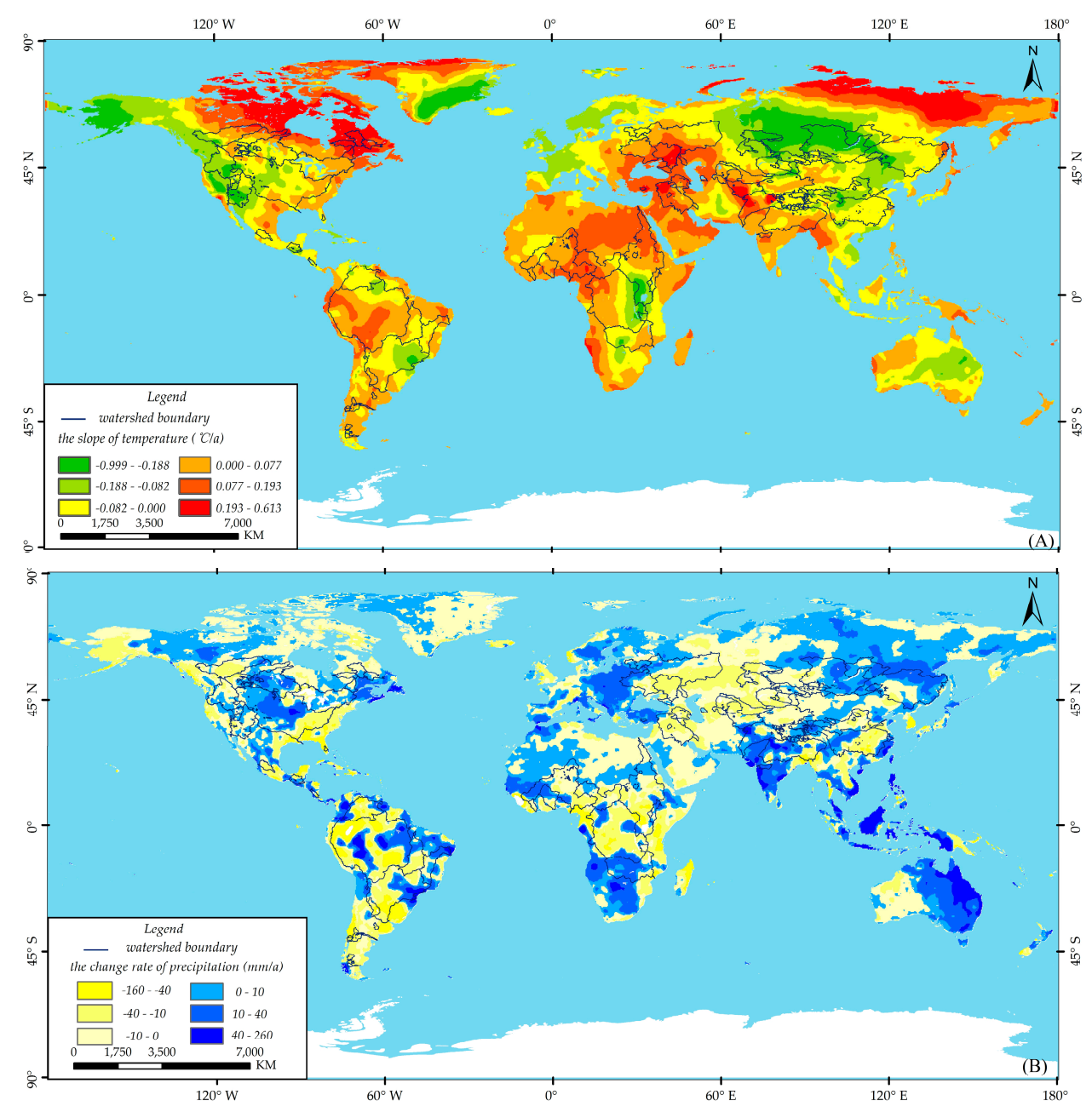

Figure 2. The change rate of global temperature (A) and precipitation (B) from 2002 to 2010. 


\subsubsection{Temperature}

The results show that the change rate of the global monthly temperature is $0.0058{ }^{\circ} \mathrm{C} / \mathrm{a}$, after analyzing the monthly GLDAS data from 2002 to 2010 (Figure 3). Overall, the Earth is warming, but the temperature largely varies in different regions (Figure 2A).

The temperature gradient on the east side of the Northern Hemisphere is $0.193{ }^{\circ} \mathrm{C} / \mathrm{a}-0.613{ }^{\circ} \mathrm{C} / \mathrm{a}$, and the temperature increase is evident. The temperature drops significantly on the west side of the Northern Hemisphere, and the temperature change rate is between $-0.082^{\circ} \mathrm{C} / \mathrm{a}$ and $0.999{ }^{\circ} \mathrm{C} / \mathrm{a}$. While the eastern side of the Southern Hemisphere is cooling, the western side is warming. The northeast and southwest regions of the Asian continent have an air temperature change rate which is greater than 0 , and most of the northeast region has a temperature gradient between $0.193{ }^{\circ} \mathrm{C} / \mathrm{a}$ and $0.613{ }^{\circ} \mathrm{C} / \mathrm{a}$. The temperature decrease with the widest margin is seen in the northeast region of China and the central region of Russia, where the change rates vary from -0.082 to $0.999{ }^{\circ} \mathrm{C} / \mathrm{a}$. In most parts of South America, the temperature change rates are greater than $0^{\circ} \mathrm{C} / \mathrm{a}$, and the fastest increasing temperatures are mainly distributed on the Brazilian Plateau and the Guyanan Plateau. The Rocky Mountains and the Central Plains in North America have change rates of less than $0{ }^{\circ} \mathrm{C} / \mathrm{a}$, and other regions have different degrees of warming. The temperature in the north-eastern part of North America has change rates between 0.193 and $0.613^{\circ} \mathrm{C} / \mathrm{a}$, demonstrating a clear increase. The temperature gradient of most parts of Africa is larger than other areas, and the temperature is evidently increasing. Only the temperatures of the South African Plateau, East African Rift Valley, and East African Plateau, are decreasing.

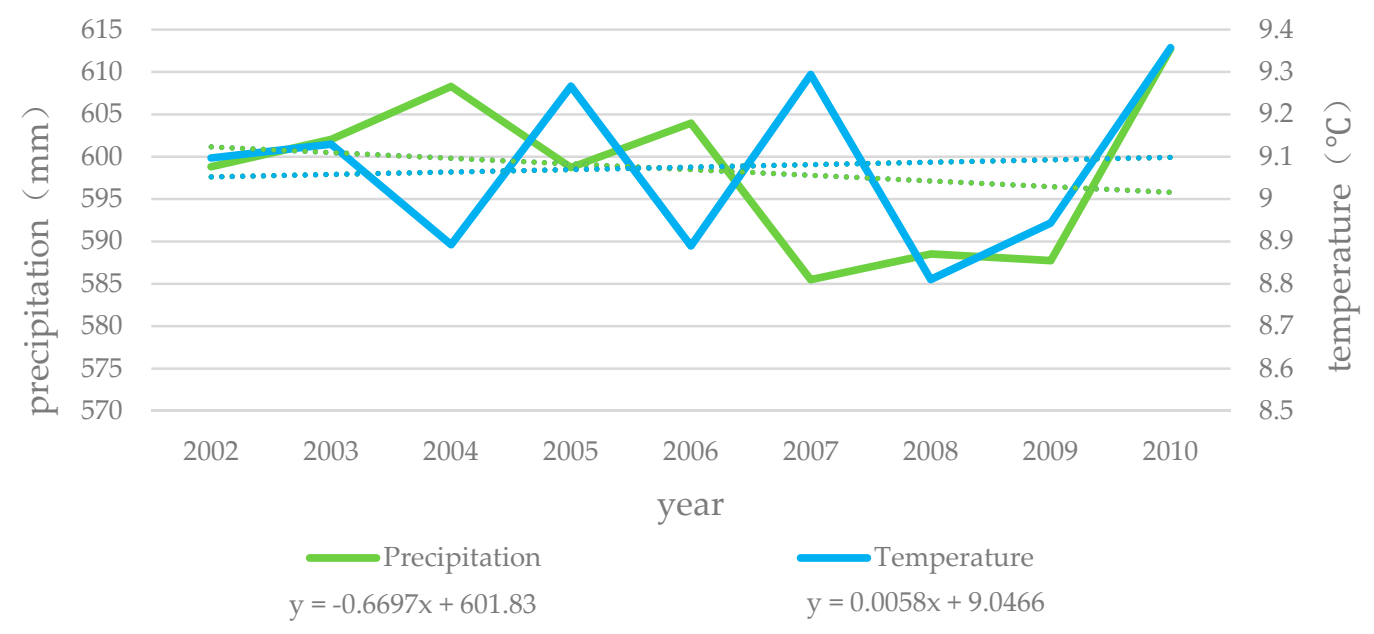

Figure 3. The trends in global temperature and precipitation.

\subsubsection{Precipitation}

The upshot shows that the global precipitation change rate is $-0.6697 \mathrm{~mm} / \mathrm{a}$ (Figure 3), by analyzing the GLDAS precipitation data for the period 2002-2010. The global precipitation rate is decreasing, but there is an obvious regional variation of precipitation tendency (Figure 2B).

Across the distribution area, the precipitation change rate is less than 0 in most parts of the world. The degree of reduction is obvious, concentrated between $-40--10 \mathrm{~mm} / \mathrm{a}$. The regional change rate of precipitation increases indistinctively, varying from 0 to $10 \mathrm{~m} / \mathrm{a}$ in most regions, demonstrating that the global total precipitation rate is decreasing. The regions with a high intensity of precipitation increase are mainly located in middle-low latitude areas, and the intensity of the precipitation increase in middle-high latitudes is relatively small. The precipitation change rates of Northeast Asia, South Asia, and the Asia Minor Peninsula, are more than $0 \mathrm{~mm} / \mathrm{a}$. Precipitation in central North America and the east of the Cabrado Peninsula is increasing, while the precipitation change rate in other regions is less than $0 \mathrm{~mm} / \mathrm{a}$. The precipitation change rates in the coastal area of the Gulf of Mexico, and the 
eastern part of Europe, are between -40 and $-10 \mathrm{~mm} / \mathrm{a}$, and this decrease is more obvious than in other regions. In South America, except for the Brazilian Plateau and the Amazon basin, the rainfall is increasing, and the rainfall in South America is variable. Increasing rainfall in South Africa is the most obvious, with the change rate of precipitation mainly being between 10 and $40 \mathrm{~mm} / \mathrm{a}$, while the precipitation change rates of most areas north of the South African Plateau are less than $0 \mathrm{~mm} / \mathrm{a}$.

\subsection{Responses of the Lake Water Level Variation to Climate Fluctuation}

\subsubsection{Response of the Lake Water Level Variation to Climate Fluctuation}

In general, the water levels of global lakes show a rising trend, and are closely related to the increases in temperature and precipitation. The global lake water level changes are mainly affected by climatic changes, but there are large differences in the degree of climatic response in different regions. The relationship between lakes and climate change is complicated.

Precipitation is an important factor affecting the change in lake levels. At the global scale, lakes with rising water levels are mainly distributed in regions with increased precipitation, such as North Central America, the Eastern European Plain, the Brazilian Plateau, the South African Plateau, and the Central Siberian Plain. The influence of precipitation on lake levels is prominent. Precipitation mainly affects lakes that are primarily supplied by precipitation and surface runoff. The effect of temperature on the lake water level is mainly reflected in two aspects. First, the temperature increase has a significant effect on the lakes due to the melting of ice and snow. The amount of melt-water increases with an increase in temperature, and the water levels of the nearby lakes show a rising trend. Second, an increase in temperature also increases the amount of evaporation. Therefore, when the increase in evaporation caused by an increase in temperature is greater than the increase in precipitation and ice melt-water supply, a decline in the lake water level will be witnessed.

\subsubsection{Response of Natural Lakes to Climate}

Compared to artificial lakes, natural lakes are subject to fewer impacts by human activities, and are more responsive to changes in global climate and the environment.

In this study, 148 of the 204 lakes are natural, and 138 natural lakes within 103 catchments are selected for the study. The average accumulated precipitation and temperature variability within each basin is counted and analyzed (Table 1). The correlation coefficient between the water level variability and accumulated precipitation is 0.258 , which is significant at the 0.01 level (2-tailed), and the correlation coefficient with accumulated temperature is -0.238 , which is a significant negative correlation at the 0.05 level (2-tailed), indicating that the effect of precipitation on the lake level is greater than that of air temperature.

Table 1. The correlation of the change rate of the average lake level and the change rate of accumulated precipitation and accumulated temperature in the basin.

\begin{tabular}{|c|c|c|c|c|}
\hline & & $\begin{array}{c}\text { The Change Rate } \\
\text { of Lake Level }\end{array}$ & $\begin{array}{l}\text { Accumulated } \\
\text { Precipitation }\end{array}$ & $\begin{array}{c}\text { Accumulated } \\
\text { Temperature }\end{array}$ \\
\hline \multirow{3}{*}{ the change rate of lake level } & Pearson Correlation & 1 & 0.258 ** & $-0.238^{*}$ \\
\hline & Sig. (2-tailed) & & 0.009 & 0.016 \\
\hline & $N$ & 103 & 103 & 103 \\
\hline \multirow{3}{*}{ accumulated precipitation } & Pearson Correlation & $0.258^{* *}$ & 1 & -0.201 * \\
\hline & Sig. (2-tailed) & 0.009 & & 0.042 \\
\hline & $N$ & 103 & 103 & 103 \\
\hline \multirow{3}{*}{ accumulated temperature } & Pearson Correlation & $-0.238^{*}$ & $-0.201 *$ & 1 \\
\hline & Sig. (2-tailed) & 0.016 & 0.042 & \\
\hline & $N$ & 103 & 103 & 103 \\
\hline
\end{tabular}

** Correlation is significant at the 0.01 level (2-tailed). * Correlation is significant at the 0.05 level (2-tailed). 
Precipitation is a significant factor affecting the lake water level. This paper analyses the impact of precipitation on the lake water level by measuring the accumulated precipitation in the basin from 2002 to 2010 (Figure 4). The result shows that 42 of the 69 drainage basins with rising lake levels are located in the region where the average accumulated precipitation is increasing. However, of 34 drainage basins with decreasing lake levels, there are only 23 watersheds whose average lake levels are decreasing when the average accumulated precipitation is dropping. The area of the increasing accumulated precipitation is mainly distributed in the center of North America, the central and southern parts of Africa, the Northern Indian peninsula, the Qinghai-Tibet Plateau, and the Central Siberian Plateau. Of the 138 lakes examined, the water level of 88 lakes is increasing. There are 51 lakes distributed in areas with increasing accumulated precipitation, and 37 lakes are distributed in areas with decreasing accumulated precipitation. Among those lakes, seven are distributed near the lower reaches of the river, and the volume of accumulated precipitation in the upper reaches of the river is increasing. Only 50 lakes have declining water levels.

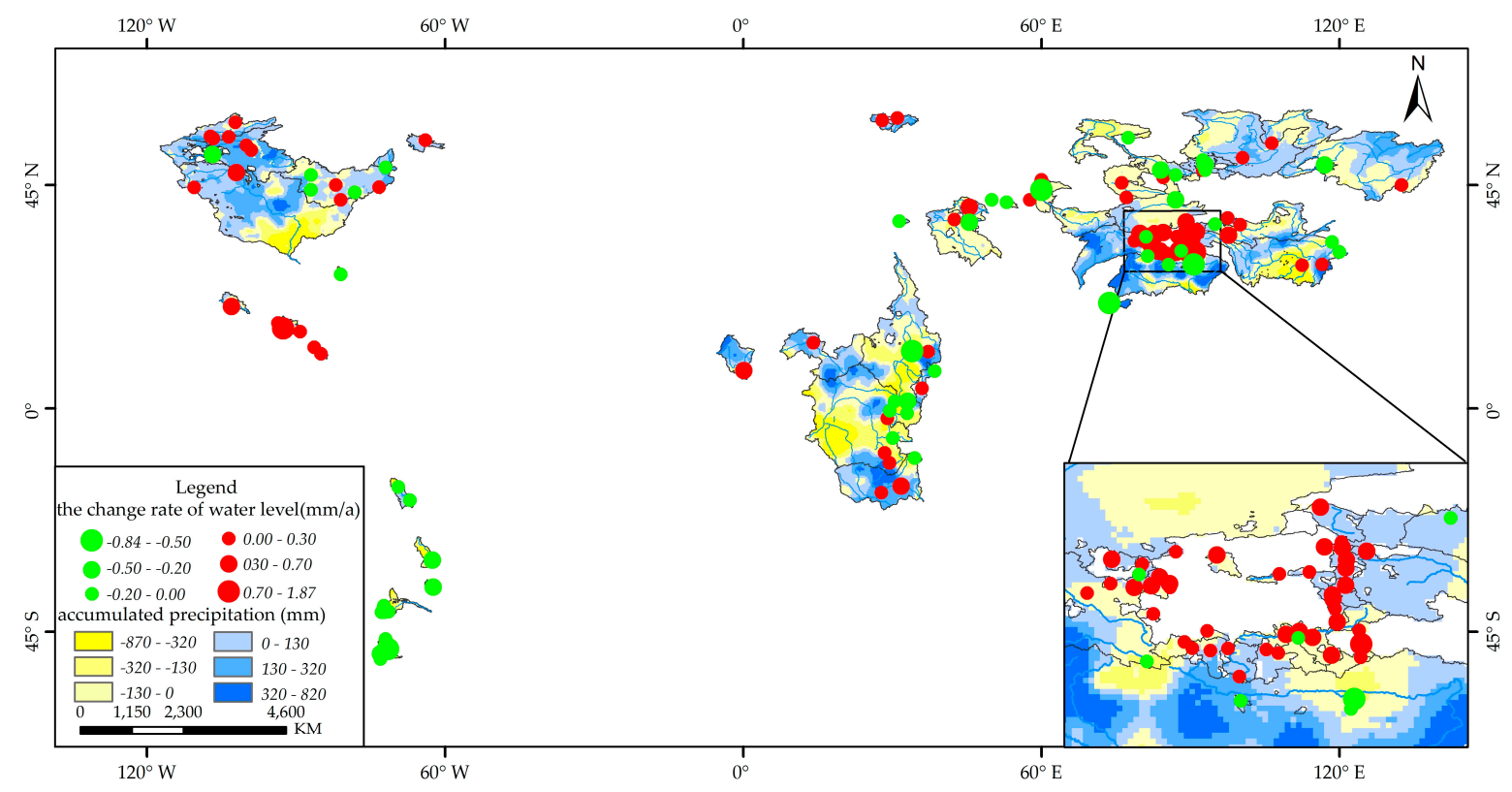

Figure 4. Accumulated precipitation and trend changes of the lake level in the watershed data.

\section{Discussion}

This paper has studied the changes in the water level of major lakes in the world, and quantitatively analyzed its response to the global climate change. Generally, of the 204 lakes discussed in this study, there are 124 lakes accounting for $2 / 3$ of the total number, with a rising water level. Pekel pointed out that the new permanent bodies of global surface water have increased by 184,000 square kilometers since 1984 . Although the permanent surface water has disappeared by almost 90,000 square kilometers elsewhere, the permanent surface water is still increasing between 1984 and 2015 [29]. However, there are obvious regional differences for the change of permanent bodies. In this way, we can also conclude that the water levels of most lakes in the world are rising. Moreover, we find that the oscillation of lake levels is not obvious between 2002 and 2010. The increasing lake levels are mainly found in the mountain plateau areas and the coastal highlands. The evidence that the mountain plateau areas and the coastal highlands are slightly affected by human activities manifests that climate change is the primary reason. However, lakes with declining water levels are chiefly situated in flatlands and valleys. The vertical distribution of the world's population is not balanced. More than $55 \%$ of the population live below $200 \mathrm{~m}$ above sea level, in the distributed flat area which accounts for less than $28 \%$ of global land area. Prigent studied the changes in land surface water dynamics 
since the 1990s and their relation to population pressure, and pointed out that the largest descents of open water are found where there are large increases in population. This indicates that a denser population can influence local hydrology by reducing the freshwater extent and by increasing water withdrawals [35]. Lake Urmia (Iraq) is the best example for explaining the conclusion. The building of a dam which intercepted nearly $90 \%$ water from three rivers flowing into Urmia for irrigation and hydropower, digging wells for freshwater, grazing, and mining near the lake, has caused the demise of Urmia. In addition, Iraq has underdone 34\% less permanent surface water losses in the past three decades $[29,43]$. The Aral Sea, which is affected by human activities, has undergone rapid desiccation and salinization since 1960. Although efforts in water management and other measures have been, and are being, made to restore the sea's water, the diversion of, and withdraw from, the Amu and Syr river that once fed the Aral Sea are the main reason for the loss [4,29].

It's found that the response of the lake level to climate change is obvious. On a global scale, the impact of climate change on lake level changes is evident. Precipitation directly affects the water level of lakes, and controls the lake with the supply of precipitation and surface runoff. For example, lake levels are rising in central North America, South Africa, and the Qinghai-Tibet Plateau, where the precipitation rate is increasing. However, the lake levels in the Great Rift Valley of East Africa are decreasing, with decreasing precipitation. The temperature has a greater impact on lakes with ice and snow melt-water as a replenishment source. The water level of most lakes on the Qinghai-Tibet Plateau is rising, which is closely related to the rising temperature of the Qinghai-Tibet Plateau in the early 2000s. As temperatures rise, the melting of glaciers and snow from the mountains causes an increase in the water supply of lakes $[15,27,44]$. For the lakes situated in semi-arid regions, precipitation is especially important under global warming. The water levels of Balkhash, the Aral Sea, and Bosten, were seen to be decreasing between 2002 and 2010, which are closely related to decreasing precipitation in this region. Meanwhile, the evaporation caused by rising temperatures and continuous drought from 2007 to 2010 is strong [18,28]. Currently, GLDAS data is widely used in global climate change research, but the authors find that GLDAS monthly temperature data show a decreasing trend on the Tibetan Plateau from 2002 to 2010, which is inconsistent with many scholars' conclusions [15-18]. Therefore, the applicability of GLDAS monthly temperature data in the Qinghai-Tibet Plateau requires further study.

In this paper, we consider the cumulative precipitation in the basin, because the change of lakes is affected by the hydrological characteristics of the river basin. There is a certain lag relationship between the precipitation and the lake water in the process of precipitation formation. Precipitation accumulation takes the effect of precipitation in the pre-period of precipitation into account, so it can better reflect the impact of precipitation on lakes [45]. Meanwhile, the impact of the river on the lake level is very significant. Despite the lake locations in the downstream area of the river and the region of reducing precipitation, the lake level will also increase if the upstream of the river witnesses increasing precipitation. In this study, the spatial distribution of the 204 lakes is not homogeneous. No lakes are studied in Oceania or Antarctica. Thus, it is also necessary to consider the lakes that are distributed on additional continents. In addition, although the lake water level is highly correlated with the lake area, this paper only analyzes the trend of the lake level. It is necessary to comprehensively analyze the lake using both the lake area and the lake water reserves. Moreover, the lake levels used are fused from satellite altimetry data from Topex/Poseidon, Jason-1 and 2, and ENVISAT. The validated results from various scholars using similar data are very good, and it is essential to apply the ice, cloud, and land elevation satellite (ICESat) altimetry data, with a higher resolution compared to other altimetry satellites, to research on the water levels of global lakes. 


\section{Conclusions}

The findings reported here will reinforce the comprehension of the impact of climate change on global lakes. The dynamic changes of lake water levels from 2002 to 2010 show that the water levels of most lakes throughout the world are generally rising. The changes in the water levels of most lakes are not obvious. Only a small number of lakes show noticeable changes. The water level fluctuation of artificial lakes (reservoirs) is more obvious than that of natural lakes. The spatial characteristics of the lake levels show that there are clear relationships between the spatial characteristics of the lake water level and its geographical location. The increasing lake levels are mainly found in the mountain plateau areas, and the coastal highlands. A few lakes located in the plains are found to have increasing lake levels. Lakes with declining water levels are mainly distributed in low-lying plains and valleys.

The meteorological data show that the global temperature increased, and precipitation decreased, from 2002 to 2010. The global temperature fluctuation indicates that the temperature increase in the high latitude areas is larger than that in the middle and low latitude regions. The eastern side of the Northern Hemisphere's continents obviously warmed, whereas the western side of the continents remained colder. The Southern Hemisphere's continents revealed the opposite, resulting in a significant regional variation in global temperature. The area with increasing global precipitation is smaller than that with decreasing precipitation, and the decreasing intensity of the precipitation is greater than the increasing intensity of the precipitation, resulting in an overall decrease in rainfall. In general, the regions with a high intensity of precipitation increase are mainly situated in middle-low latitude areas, and the intensity of the precipitation increase in middle-high latitudes is relatively small. Regions with increasing precipitation are concentrated in coastal areas, especially in coastal flatlands. However, regions with decreasing precipitation are mainly located in inland areas.

The influence of precipitation changes on the lake level is greater than the effect of temperature. Precipitation directly affects the lake level changes. However, the impact of temperature on the lake level is more complicated. On the one hand, the temperature increase has a significant effect on the lakes, thanks to the melting of ice and snow. The amount of melt-water increases with the increase of temperature, and the water levels of the nearby lakes show a rising trend. Furthermore, an increase in temperature also increases the amount of evaporation. When the increased evaporation caused by an increase in temperature is greater than the increase in precipitation and ice melt-water supply, there will be a decline in the lake water level. Lakes with rising water levels are mainly distributed in regions with increased precipitation, and precipitation mainly affects lakes that are primarily supplied by precipitation and surface runoff. However, the region with an abundant accumulated precipitation is not completely located in the same area as the lakes with obviously rising water levels, indicating that the lake water level is synthetically affected by precipitation, temperature, evaporation, and other meteorological factors, along with human activities. At the same time, the impact of human activities on the lake water level cannot be ignored, and the specific impact of human activities on lakes requires further study.

Acknowledgments: This study is supported by the Fundamental Research Funds for the Central Universities (grant number: SWU114108), the National Key Technology R\&D Program of China (grant number: 2016YFC0500106) and the Special Project of Science and Technology Basic Work (grant number: 2014FY210800-5). In this study, multi-resource data are downloaded from different data centers. These data include LEGOS lake area data, Hydro SHEDS Watershed data, and GLDAS-1 temperature and air temperature data. The authors express their gratitude for the data sharing of the above dataset. We sincerely appreciate the four anonymous reviewers' valuable comments and suggestions and the editor's efforts in improving this manuscript.

Author Contributions: Mingguo Ma and Honghai Kuang designed the case study. Chao Tan processed the data. Chao Tan and Mingguo Ma wrote the paper. All of the authors contributed to the discussion of the results.

Conflicts of Interest: The authors declare no conflict of interest. 


\section{Appendix A}

Table A1. The change rates of the lake levels in 2002-2010.

\begin{tabular}{|c|c|c|c|c|c|}
\hline Sequence & Lake & $\begin{array}{c}\text { Change Rate } \\
(\mathrm{m} / \mathrm{a})\end{array}$ & Sequence & Lake & $\begin{array}{c}\text { Change Rate } \\
(\mathrm{m} / \mathrm{a})\end{array}$ \\
\hline 1 & Angostura * & 1.867 & 103 & Khanka * & 0.036 \\
\hline 2 & Oahe & 1.03 & 104 & Nicaragua * & 0.036 \\
\hline 3 & Tres Marias & 1.022 & 105 & Baikal * & 0.031 \\
\hline 4 & Guri & 0.982 & 106 & Issykkul * & 0.03 \\
\hline 5 & Tucurui & 0.802 & 107 & Great Bear* & 0.029 \\
\hline 6 & Dogen-co* & 0.758 & 108 & Montreal * & 0.029 \\
\hline 7 & Volta * & 0.68 & 109 & Vanerm * & 0.027 \\
\hline 8 & Zeyskoye & 0.667 & 110 & Har Us * & 0.027 \\
\hline 9 & Ziling* & 0.606 & 111 & Kainji & 0.026 \\
\hline 10 & Sakakawea * & 0.604 & 112 & Tchad * & 0.019 \\
\hline 11 & Dorsoidong-co * & 0.583 & 113 & Izabal * & 0.015 \\
\hline 12 & Xuelian-hu * & 0.569 & 114 & Aru-co ${ }^{*}$ & 0.015 \\
\hline 13 & Sobradino & 0.554 & 115 & Hovsgol * & 0.013 \\
\hline 14 & Dagze-co * & 0.552 & 116 & Huron * & 0.012 \\
\hline 15 & Posadas & 0.505 & 117 & Kapchagayskoye & 0.01 \\
\hline 16 & Cahora Bassa * & 0.482 & 118 & Dubawnt & 0.009 \\
\hline 17 & Memar-co * & 0.474 & 119 & Erie $^{*}$ & 0.009 \\
\hline 18 & Yanghu-co * & 0.467 & 120 & Balkhash * & 0.007 \\
\hline 19 & Chapala * & 0.453 & 121 & Maracaibo & 0.007 \\
\hline 20 & Krasnoyarskoye & 0.435 & 122 & Tana * & 0.006 \\
\hline 21 & Hoh-xil-hu * & 0.434 & 123 & Kivu * & 0.004 \\
\hline 22 & Kyeb * & 0.414 & 124 & Lesser Slave & 0.003 \\
\hline 23 & Lumojangdong-co * & 0.364 & 125 & Ontario * & -0.001 \\
\hline 24 & Xiangyang-hu * & 0.364 & 126 & Michigan * & -0.002 \\
\hline 25 & Sevana * & 0.352 & 127 & Amadjuak & -0.004 \\
\hline 26 & Caniapiscau & 0.345 & 128 & Athabasca * & -0.0077 \\
\hline 27 & Xijir-hulan-hu * & 0.345 & 129 & Rinihue* & -0.008 \\
\hline 28 & Saksak & 0.343 & 130 & Baker & -0.011 \\
\hline 29 & Grande Trois & 0.343 & 131 & Logoa dos Patos* & -0.011 \\
\hline 30 & Lisioidain-co * & 0.337 & 132 & Saint-Jean * & -0.014 \\
\hline 31 & Ngoring-co * & 0.326 & 133 & Tanganika * & -0.015 \\
\hline 32 & Aksayqin * & 0.325 & 134 & Logoa Gen Carrera * & -0.015 \\
\hline 33 & Migruggwangkum * & 0.324 & 135 & Dabsan-hu* & -0.017 \\
\hline 34 & Serbug-co * & 0.318 & 136 & Votkinskoye & -0.018 \\
\hline 35 & Ulan-ul * & 0.314 & 137 & Superior ${ }^{*}$ & -0.018 \\
\hline 36 & Ayakkum * & 0.312 & 138 & Caspian Sea * & -0.019 \\
\hline 37 & Bul-co * & 0.312 & 139 & Kyyvske & -0.021 \\
\hline 38 & Gyeze-caka * & 0.307 & 140 & $\mathrm{Tai}^{*}$ & -0.023 \\
\hline 39 & Luotuo-hu * & 0.306 & 141 & Uvs * & -0.024 \\
\hline 40 & Taro-co * & 0.297 & 142 & Nettiling & -0.024 \\
\hline 41 & Sarykamish * & 0.291 & 143 & Chardarya & -0.026 \\
\hline 42 & Ngangze * & 0.283 & 144 & Orba-co * & -0.026 \\
\hline 43 & Zige-tangco * & 0.282 & 145 & Kremenchutska & -0.028 \\
\hline 44 & Co-nyi * & 0.28 & 146 & Argentino* & -0.028 \\
\hline 45 & Dawa-co * & 0.28 & 147 & Malawi * & -0.031 \\
\hline 46 & Heishi-beihu * & 0.276 & 148 & Great Slave* & -0.032 \\
\hline 47 & $\operatorname{Aral}($ Nord) $*$ & 0.243 & 149 & Todos los Santos * & -0.033 \\
\hline 48 & Dogaicoring * & 0.23 & 150 & Hongze * & -0.034 \\
\hline 49 & Kushuihuan * & 0.229 & 151 & Kara Bogaz Gol * & -0.037 \\
\hline 50 & Tangra-yumco * & 0.216 & 152 & Edouard * & -0.038 \\
\hline 51 & Iguazu & 0.215 & 153 & Uru-co * & -0.038 \\
\hline 52 & Deschambault * & 0.21 & 154 & Great Salt & -0.04 \\
\hline 53 & Bratskoye & 0.192 & 155 & Shala * & -0.043 \\
\hline 54 & Namco * & 0.182 & 156 & Aylmer & -0.046 \\
\hline 55 & Lagor-co * & 0.17 & 157 & Tchany * & -0.05 \\
\hline 56 & Managua * & 0.166 & 158 & Har* & -0.055 \\
\hline 57 & Yaggain-canco * & 0.155 & 159 & Llanquihue * & -0.056 \\
\hline 58 & Aydarkul & 0.154 & 160 & Ulungur* & -0.057 \\
\hline 59 & Winnipegosis * & 0.154 & 161 & Flathead & -0.062 \\
\hline 60 & Caribou * & 0.148 & 162 & Beysehir* & -0.064 \\
\hline
\end{tabular}


Table A1. Cont.

\begin{tabular}{|c|c|c|c|c|c|}
\hline Sequence & Lake & $\begin{array}{l}\text { Change Rate } \\
(\mathrm{m} / \mathrm{a})\end{array}$ & Sequence & Lake & $\begin{array}{c}\text { Change Rate } \\
(\mathrm{m} / \mathrm{a})\end{array}$ \\
\hline 61 & Har-hu * & 0.147 & 163 & Victoria * & -0.066 \\
\hline 62 & Chem-co * & 0.146 & 164 & Puma-yumco * & -0.072 \\
\hline 63 & San Martin * & 0.145 & 165 & Kuybyshevskoye & -0.084 \\
\hline 64 & Illmen * & 0.136 & 166 & Mapam-yamco * & -0.085 \\
\hline 65 & Gozha-co * & 0.128 & 167 & Nahuelhuapi * & -0.121 \\
\hline 66 & Balbina & 0.121 & 168 & Tsimlyanskoye & -0.124 \\
\hline 67 & Tshchikskoye & 0.118 & 169 & Nasser & -0.128 \\
\hline 68 & Zhari-namco * & 0.114 & 170 & Churumuco & -0.128 \\
\hline 69 & Aong-co * & 0.109 & 171 & Okeechobee * & -0.128 \\
\hline 70 & Kariba * & 0.106 & 172 & Aberdeen & -0.129 \\
\hline 71 & pangong-co * & 0.101 & 173 & Khantaiskoye * & -0.145 \\
\hline 72 & Nezahualcoyoti * & 0.1 & 174 & Asad & -0.146 \\
\hline 73 & Ladoga * & 0.094 & 175 & Poopo * & -0.15 \\
\hline 74 & Winnipeg * & 0.094 & 176 & Ranco * & -0.159 \\
\hline 75 & Furnas & 0.089 & 177 & Pelkhu-co * & -0.168 \\
\hline 76 & Cedar & 0.085 & 178 & Titicaca * & -0.189 \\
\hline 77 & Opinaca & 0.083 & 179 & Albert* & -0.19 \\
\hline 78 & Rybinskoye & 0.082 & 180 & Rukwa & -0.203 \\
\hline 79 & Qinghai* & 0.078 & 181 & Kyoga* & -0.216 \\
\hline 80 & Dore * & 0.073 & 182 & Viedma * & -0.22 \\
\hline 81 & Manitoba * & 0.073 & 183 & Old Wives * & -0.232 \\
\hline 82 & Vatern * & 0.072 & 184 & Hyargas* & -0.29 \\
\hline 83 & Bangweulu * & 0.067 & 185 & Bosten * & -0.3 \\
\hline 84 & Itaparica & 0.065 & 186 & Saysan * & -0.32 \\
\hline 85 & Mweru * & 0.0625 & 187 & Williston & -0.333 \\
\hline 86 & Nueltin & 0.062 & 188 & Hulun * & -0.338 \\
\hline 87 & Des Bois & 0.061 & 189 & Cardiel * & -0.344 \\
\hline 88 & Kasba & 0.06 & 190 & Chiquita * & -0.347 \\
\hline 89 & Peipus* & 0.058 & 191 & Urmia * & -0.394 \\
\hline 90 & Smallwood * & 0.058 & 192 & Hinojo * & -0.418 \\
\hline 91 & Onega * & 0.056 & 193 & Razazah & -0.422 \\
\hline 92 & Dongting * & 0.055 & 194 & Tharthar & -0.464 \\
\hline 93 & Turkana * & 0.055 & 195 & Saravor * & -0.516 \\
\hline 94 & Van * & 0.053 & 196 & Roseires * & -0.533 \\
\hline 95 & Rinqiyubu-co * & 0.052 & 197 & $\operatorname{Aral}(\mathrm{Sud}) *$ & -0.569 \\
\hline 96 & Poyang * & 0.047 & 198 & Yamzho-yumco * & -0.599 \\
\hline 97 & Powell & 0.0456 & 199 & Strobel * & -0.84 \\
\hline 98 & Champlain * & 0.044 & 200 & Buyo & -0.954 \\
\hline 99 & Nganga-ringko * & 0.042 & 201 & Qadisiyah & -1.608 \\
\hline 100 & Sasykkol * & 0.04 & 202 & Mossoul & -1.8 \\
\hline 101 & Yellowstone * & 0.039 & 203 & Mead & -2.356 \\
\hline 102 & Ilha Solteira & 0.038 & 204 & Toktogul & -5.844 \\
\hline
\end{tabular}

Note: * presents natural lake.

\section{References}

1. Lv, X.; Wu, S.; Yang, Q. An assessment of global environmental change and its impacts on the regional development in China. Prog. Geogr. 2003, 22, 160-169.

2. Jiang, Y.; Li, S.; Shen, D.; Chen, W.; Jin, C. Climate Change and its impact on the lake environment in the Tibetan Plateau in 1971-2008. Sci. Geogr. Sin. 2012, 32, 1503-1512.

3. Ma, M.; Wang, X.; Veroustraete, F. Change in area of Ebinur Lake during the 1998-2005 period. Int. J. Remote Sens. 2007, 28, 5523-5533. [CrossRef]

4. Micklin, P. The future Aral Sea: Hope and despair. Environ. Earth Sci. 2016. [CrossRef]

5. Zhang, Z.; Wang, N.; Wu, Y.; Shen, S.; Zhang, X.; Chang, J. Remote sensing on spatial changes of lake area in Badain Jaran Desert hinterland during 1973-2010. J. Lake Sci. 2013, 25, 514-520.

6. Zhu, W.; Jia, S.; Aifeng, L.V. Monitoring the fluctuation of Lake Qinghai using multi-source remote sensing data. Remote Sens. 2014, 6, 10457-10482. [CrossRef]

7. Bai, J.; Chen, X.; Li, J.; Yang, L. Changes of inland lake area in arid Central Asia during 1975-2007: Remote sensing analysis. J. Lake Sci. 2011, 23, 80-88. 
8. Zhang, X.; Wu, Y.; Zhang, X. Water level variation of inland lakes on the south-central Tibetan Plateau in 1972-2012. Acta Geogr. Sin. 2014, 69, 993-1001.

9. Li, J.; Chen, X.; Bao, A. Spatial-temporal Characteristics of Lake Level Changes in Central Asia during 2003-2009. Acta Geogr. Sin. 2011, 66, 1219-1229.

10. Duan, Z.; Bastiaanssen, W.G.M. Estimating water volume variations in lakes and reservoirs from four operational satellite altimetry databases and satellite imagery data. Remote Sens. Environ. 2013, 134, 403-416. [CrossRef]

11. Muala, E.; Mohamed, Y.A.; Duan, Z.; Zaag, P.V.D. Estimation of Reservoir discharges from Lake Nasser and Roseires Reservoir in the Nile Basin using satellite altimetry and imagery data. Remote Sens. 2014, 6, 7522-7545. [CrossRef]

12. Medina, C.; Gomez-Enri, J.; Alonso, J.J.; Villares, P. Water volume variations in Lake Izabal (Guatemala) from in situ measurements and ENVISAT Radar Altimeter (RA-2) and Advanced Synthetic Aperture Radar (ASAR) data products. J. Hydrol. 2010, 382, 34-48. [CrossRef]

13. Frappart, F.; Do Minh, K.; L'hermitte, K.; Cazenave, A.; Ramillien, G.; Le Toan, T.; Mognard-Campbell, N. Water volume change in the lower Mekong from satellite altimetry and imagery data. Geophys. J. Int. 2006, 167, 570-584. [CrossRef]

14. Silva, J.S.D.; Calmant, S.; Seyler, F. Water levels in the Amazon basin derived from the ERS 2 and ENVISAT radar altimetry missions. Remote Sens. Environ. 2010, 114, 2160-2181. [CrossRef]

15. Kleinherenbrink, M.; Lindenbergh, R.C.; Ditmar, P.G. Monitoring of lake level changes on the Tibetan Plateau and Tian Shan by retracking Cryosat SARIn waveforms. J. Hydrol. 2015, 521, 119-131. [CrossRef]

16. Song, C.; Huang, B.; Ke, L. Modeling and analysis of lake water storage changes on the Tibetan Plateau using multi-mission satellite data. Remote Sens. Environ. 2013, 135, 25-35. [CrossRef]

17. Zhang, G.; Xie, H.; Duan, S.; Tian, M.; Yi, D. Water level variation of Lake Qinghai from satellite and in situ measurements under climate change. J. Appl. Remote Sens. 2011, 5, 053532. [CrossRef]

18. Zhang, G.; Xie, H.; Kang, S.; Yi, D. Monitoring lake level changes on the Tibetan Plateau using ICESat altimetry data (2003-2009). Remote Sens. Environ. 2011, 115, 1733-1742. [CrossRef]

19. Wang, X.; Gong, P.; Zhao, Y.; Xu, Y.; Cheng, X. Water-level changes in China's large lakes determined from ICESat/GLAS data. Remote Sens. Environ. 2013, 132, 131-144. [CrossRef]

20. Wang, X.; Wang, W.; Wang, P. Assessing Applicability of GLDAS Monthly Temperature Data in China. Water Resour. Power 2014, 25, 769-778.

21. Wang, W.; Wang, X.; Wang, P. Assessing the applicability of GLDAS monthly precipitation data in China. Adv. Water Sci. 2014, 25, 769-778.

22. Hou, Y.; Nan, Z.; Pan, X. Comparative evaluation of WRF and GLDAS precipitation data over the upper Heihe River basin. J. Lanzhou Univ. 2013, 49, 437-447.

23. Wang, A.; Zeng, X. Evaluation of multire analysis products with in situ observations over the Tibetan Plateau. J. Geophys. Res. Atmos. 2012, 117. [CrossRef]

24. Li, X.; Gao, Y.; Wang, W.; Lan, Y.; Xu, J.; Li, K. Climate change and applicability of GLDAS in the headwater of the Yellow River Basin. Adv. Earth Sci. 2014, 4, 531-540.

25. Crétaux, J.-F.; Jelinski, W.; Calmant, S.; Kouraev, A.; Vuglinski, V. SOLS: A lake database to monitor in the Near Real Time water level and storage variations from remote sensing data. Adv. Space Res. 2011, 47, 1497-1507. [CrossRef]

26. Wang, F.; Wang, L.; Koike, T.; Zhou, H.; Yang, K.; Wang, A.; Li, W. Evaluation and application of a fine-resolution global data set in a semiarid mesoscale river basin with a distributed biosphere hydrological model. J. Geophys. Res. Atmos. 2011, 116. [CrossRef]

27. Song, C.; Huang, B.; Ke, L.; Richards, K.S. Seasonal and abrupt changes in the water level of closed lakes on the Tibetan Plateau and implications for climate impacts. J. Hydrol. 2014, 514, 131-144. [CrossRef]

28. Bai, J.; Chen, X.; Li, J.; Yang, L.; Fang, H. Changes in the area of inland lakes in arid regions of central Asia during the past 30 years. Environ. Monit. Assess. 2011, 178, 247-256. [CrossRef] [PubMed]

29. Pekel, J.-F.; Cottam, A.; Gorelick, N.; Belward, A.S. High-resolution mapping of global surface water and its long-term changes. Nature 2016, 540, 418-422. [CrossRef] [PubMed]

30. Hydroweb. Available online: http://www.legos.obs--mip.fr/fr/soa/hydrologie/hydroweb/ (accessed on 13 February 2017). 
31. Yan, L.; Zheng, M.; Wei, L. Change of the lakes in Tibetan Plateau and it's response to climate in the past forty years. Earth Sci. Front. 2016, 23, 310-323.

32. Hydrology from Space. Lakes, Rivers and Wetlands Water Levels from Satellite Altimetry. Available online: http://www.legos.obs-mip.fr/soa/hydrologie/hydroweb/ (accessed on 8 January 2014).

33. Crétaux, J.-F.; Calmant, S.; Abarca Del Rio, R.; Kouraev, A. Lakes studies from satellite altimetry. In Handbook on Coastal Altimetry; Springer: Berlin/Heidelberg, Germany, 2010.

34. Shum, C.; Yi, Y.; Cheng, K.; Kuo, C. Calibration of Jason-1 Altimeter over Lake Erie. Mar. Geod. 2003, 26, 335-354. [CrossRef]

35. Crétaux, J.-F.; Birkett, C. Lake studies from satellite altimetry. C. R. Geosci. 2006, 338, 1098-1112. [CrossRef]

36. Prigent, C.; Papa, F.; Aires, F.; Jimenez, C.; Rossow, W.B.; Matthews, E. Changes in land surface water dynamics since the 1990s and relation to population pressure. Geophys. Res. Lett. 2012, 39, L08403. [CrossRef]

37. The USGS HydroSHEDS. Available online: http://hydrosheds.cr.usgs.gov/dataavail.php (accessed on 13 February 2017).

38. Global Land Assimilation System (GLDAS). Available online: http://disc.sci.gsfc.nasa.gov/uui/datasets? keywords=GLDAS (accessed on 13 February 2017).

39. Bian, D.; Du, J.; Hu, J.; Li, C.; Li, L. Response of the Water Level of the Yamzho Yumco to Climate Change during 1975-2006. J. Glaciol. Geocryol. 2009, 31, 404-409.

40. Chu, D.; Pu, Q.; Laba, Z.; Zhu, L.; Zhang, X.; Pubu, C.; Deji, Y.; Sun, R. Remote sensing analysis on lake area variations of Yamzho Yumco in Tibetan Plateau over the past 40 a. J. Lake Sci. 2012, 24, 494-502.

41. Deng, H.; Chen, Y.; Shi, X. Dynamics of temperature and precipitation extremes and their spatial variation in the arid region of northwest China. Atmos. Res. 2014, 138, 346-355. [CrossRef]

42. Insaf, T.Z.; Lin, S.; Sheridan, S.C. Climate trend in indices for temperature and precipitation across New York State, 1948-2008. Air Qual. Atmos. Health 2012, 6, 247-257. [CrossRef]

43. Stone, R. Saving Iran's Great Salt Lake. Science 2015, 349, 1044-1047.

44. Song, C.; Huang, B.; Ke, L.-H. Heterogeneous change patterns of water level for inland lakes in High Mountain Asia derived from multi-mission satellite altimetry. Hydrol. Process. 2015, 29, 2769-2781. [CrossRef]

45. Ding, Y.; Liu, S.; Ye, B.; Zhao, L. Climatic Implications on Variations of Lakes in the Cold and Arid Regions of China during the Recent 50 Years. J. Glaciol. Geocryol. 2006, 28, 623-632.

(C) 2017 by the authors; licensee MDPI, Basel, Switzerland. This article is an open access article distributed under the terms and conditions of the Creative Commons Attribution (CC BY) license (http:/ / creativecommons.org/licenses/by/4.0/). 